\title{
BRANDING NARODOWY - CO TO JEST? UWAGI DO TOCZĄCEJ SIĘ DYSKUSJI
}

\author{
NATION BRANDING - WHAT IS IT? \\ REMARKS ON THE ONGOING DISCUSSION
}

\author{
Anna Quirin*
}

\begin{abstract}
ABSTRAKT
Artykuł stanowi krytyczny przegląd podejść teoretycznych do fenomenu brandingu narodowego. Rozważania otwiera omówienie idei przewodniej oraz podstawowych założeń, na których opiera się branding narodowy, wraz z próbą odpowiedzi na pytanie o przyczyny jego aktualnej popularności. Następnie są prezentowane dominujące podejścia teoretyczne oraz omawiane najważniejsze definicje. Celem nadrzędnym poniższego artykułu jest sprawdzenie, czy można mówić o jednej, spójnej, powszechnie akceptowanej koncepcji brandingu narodowego. Autorka artykułu konkluduje, że raczej mamy do czynienia z wieloma odmiennymi koncepcjami, które łączą wspólne elementy.
\end{abstract}

Słowa kluczowe: branding narodowy, reputacja kraju, wizerunek kraju, marka narodowa
The article gives a critical overview of theoretical approaches to the phenomenon of nation branding. It begins with an explanation of the core idea and main assumptions, which nation branding is based on, combined with a trial of giving an answer to a question of reasons of its current popularity. After that, it presents dominant theoretical approaches to nation branding and discusses the most significant definitions. The prime goal of the article is to prove whether we can speak of one, coherent, generally accepted concept of nation branding or not. The author of the article concludes that we rather have to deal with many different concepts, which are connected by common elements.

Keywords: nation branding, country reputation, country image, nation brand

\footnotetext{
* Uniwersytet Mikołaja Kopernika w Toruniu, Wydział Politologii i Studiów Międzynarodowych.
} 
Niniejszy artykuł stanowi krytyczny przegląd podejść teoretycznych do fenomenu brandingu narodowego. Rozważania otworzy omówienie idei przewodniej oraz podstawowych założeń, na których opiera się branding narodowy, wraz z próbą odpowiedzi na pytanie o przyczyny jego aktualnej popularności. Następnie zaprezentowane zostaną dominujące podejścia teoretyczne oraz omówione najważniejsze definicje. Celem nadrzędnym poniższego artykułu jest sprawdzenie, czy można w przypadku brandingu narodowego mówić o jednej, spójnej, powszechnie akceptowanej koncepcji, czy raczej mamy do czynienia $\mathrm{z}$ wieloma odmiennymi koncepcjami, które łączą wspólne elementy.

\section{IDEA BRANDINGU NARODOWEGO}

Branding narodowy jest stosunkowo młodym fenomenem (pojęcie brandingu narodowego do obiegu naukowego i praktycznego wprowadził w 1996 Simon Anholt), który w przeciągu niespełna 20 lat swojego istnienia zrobił zawrotną karierę zarówno na polu naukowym, jak i w praktyce. The New York Times Magazine uznał go za jedną z wielkich idei roku 2005, a stało się to krótko po tym, jak brytyjski ekspert ds. brandingu, Simon Anholt, opublikował swoją książkę Brand America: The Mother of All Brands ${ }^{1}$. Anholt tak wyjaśnia współczesne zainteresowanie brandingiem narodowym: „Just as companies have learned to "live the brand", countries should consider their reputations carefully - because [...] in the interconnected world, that's what statecraft is all about" (Risen, 2005).

Punktem wyjścia do rozważań nad brandingiem narodowym jest postrzeganie roli i pozycji państwa w świecie w kategoriach konkurencji. Konkurencja między państwami nie ogranicza się przy tym do walki o rynki zbytu dla rodzimych produktów czy ochrony tychże przed zalewem produktów zagranicznych. Państwa konkurują o turystów, inwestorów, ludzi sztuki czy wysoko wykwalifikowanych specjalistów. Także zdobywanie wpływów politycznych i ekonomicznych, uczestnictwo $\mathrm{w}$ sojuszach i porozumieniach międzynarodowych są $\mathrm{w}$ tym kontekście postrzegane jako elementy walki konkurencyjnej. Jak pisze Anholt w Brand America: „[...] today's community of nations is open, transparent and

1 Anholt, S., Hildreth, J. (2004). Brand America: The Mother of All Brands. United Kingdom: Cyan Books. W Polsce książka wydana została w 2005 r. przez Instytut Marki Polskiej pt. Brand America. Tajemnica Megamarki. 
substantially democratic - in many ways - like a marketplace and [...] the state's reputation is therefore of critical importance" (Anholt, Hildreth, 2010, s. 135).

Reputacja i wizerunek danego kraju za granicą, obraz jego mieszkańców oraz wytwarzanych w nim wyrobów uzyskują w takiej interpretacji centralne znaczenie na polu walki konkurencyjnej. Zarówno reputacja, jak i wizerunek są elementami „miękkiej” siły państwa (soft power), rozumianej jako siła „przyciągania” lub siła „uwodzenia”, której Joseph S. Nye przypisuje we współczesnym świecie tę samą wagę, jaką posiada siła „twarda” (hard power), czyli siła gospodarcza i militarna danego $\mathrm{kraju}^{2}$. Peter van Ham w swoim wielokrotnie cytowanym artykule The Rise of the Brand State stwierdza wręcz, iż mamy obecnie do czynienia ze zmianą paradygmatu politycznego, w wyniku której współczesny świat geopolityki i siły przekształca się w postmodernistyczny świat wizerunku i wpływu: „[...] it implies a shift in political paradigms, a move from the modern world of geopolitics and power to the postmodern world of images and influence"(van Ham, 2011, s. 4).

Przyczyn wzrostu znaczenia wizerunku i reputacji państwa na arenie międzynarodowej, a tym samym wzrostu popularności brandingu narodowego należy doszukiwać się przede wszystkim w postępujących procesach globalizacyjnych i integracyjnych, które z jednej strony przyczyniają się do homogenizacji rynków światowych, $\mathrm{z}$ drugiej zaś powodują wzrost wagi przypisywanej tożsamości narodowej (Eitel, 2013). Jak zauważa Michael E. Porter (2001, s. 191): „W świecie narastającej konkurencji globalnej znaczenie narodów wzrosło, a nie zmalało". Różnice w narodowych wartościach, kulturze, strukturach gospodarczych, instytucjach i historii przyczyniają się do powodzenia w walce konkurencyjnej, stanowiąc pozytywne wyróżniki, które zgodnie z tzw. efektem kraju pochodzenia (country-of-origin effect - COO) wpływają na proces podejmowania decyzji. Ponadto rewolucje technologiczne oraz rozwój nowych mediów zwiększają widoczność państw w środowisku międzynarodowym oraz umożliwiają aktywny udział podmiotów niepaństwowych we współczesnych stosunkach międzynarodowych, a co za tym idzie - wzrost znaczenia międzynarodowej opinii publicznej.

Myślenie o państwie w kategoriach brandingu narodowego opiera się na założeniu o występowaniu analogii pomiędzy państwem a przedsiębiorstwem

2 Koncepcję „miękkiej” siły Joseph S. Nye zaproponował w 2004 r.: Nye, J.S. (2004). Soft Power. The Means to Success in World Politics. New York: Public Affairs. Polskie tłumaczenie pt. Soft power. Jak osiagnąć sukces w polityce światowej ukazało się nakładem Wydawnictw Akademickich i Profesjonalnych w $2007 \mathrm{r}$. 
(zwłaszcza dużą korporacją). Takie podejście reprezentuje m. in. Marta Hereźniak, autorka prawdopodobnie najważniejszego polskojęzycznego kompendium wiedzy na temat strategii, metod i narzędzi budowania marki państwa w kontekście wyzwań globalnej gospodarki. Analogia ta dotyczy zarówno zasad funkcjonowania, priorytetów, sposobów zarządzania oraz wykorzystywanych instrumentów (Hereźniak, 2011). Państwa, podobnie jak firmy, potrzebują strategii pozycjonowania, w której zdefiniowane i uporządkowane zostają strategiczne priorytety państwa oraz wizja jego rozwoju. Taka strategia umożliwia efektywną realizację wyznaczonych priorytetów, a tym samym ułatwia komunikację z najważniejszymi grupami interesariuszy. Pytania o tożsamość, wizję, kluczowe kompetencje, źródła wartości dodanej oraz o kanały komunikacji stawiane przy opracowywaniu długofalowej strategii rozwoju państwa dotykają istoty brandingu narodowego (Hereźniak, 2011). „Marka jest bowiem najbardziej widoczną, symboliczną manifestacją wymienionych elementów, branding zaś procesem nadawania tożsamości i pozytywnego wyróżnienia” (Hereźniak, 2011, s. 20).

Dbanie o reputację kraju i kreowanie jego pozytywnego wizerunku za granicą nie jest zjawiskiem nowym w obszarze stosunków międzynarodowych. W przeszłości aktywność na tym polu była domeną dyplomatów i odbywała się przeważnie na poziomie stosunków dyplomatycznych (Eitel, 2013). Współczesne postrzeganie pozycji państwa na arenie międzynarodowej w kategoriach konkurencji sprawia, iż zidentyfikowanie przewag konkurencyjnych, jakimi dysponuje dane państwo, ich wspieranie oraz nade wszystko odpowiednie o nich informowanie zarówno odbiorców krajowych, jak i zagranicznych, staje się koniecznością i zadaniem każdego rządu. W dyskusje na temat międzynarodowego image'u i reputacji kraju włączane są często szerokie kręgi elit politycznych, gospodarczych i kulturalnych danego kraju, a w celu budowania i zarządzania reputacją kraju wykorzystywane są nowoczesne koncepcje, takie jak omawiany tutaj branding narodowy, zakładający, że każde państwo może być postrzegane jako marka, i że mechanizmy budowania i zarządzania markami komercyjnymi mogą być wykorzystane w procesie budowania i zarządzania marką narodową. Biorąc pod uwagę rosnącą intensywność, z jaką kraje na całym świecie stosują tę koncepcję (van Ham, 2011; Anholt, 2007; Eitel, 2013), nie mam wątpliwości, iż mamy tutaj do czynienia ze wzrastającym fenomenem, który coraz częściej będzie zajmował centralne miejsce w różnych obszarach badań naukowych. 


\section{PODEJŚCIA TEORETYCZNE DO BRANDINGU NARODOWEGO}

Najtrafniejszą moim zdaniem kategoryzację podejść teoretycznych do brandingu narodowego zaprezentowała badaczka z University of Denver, Nadia Kaneva (2011). W swojej obszernej analizie literatury przedmiotu wyróżnia trzy podejścia: podejście ekonomiczno-techniczne, podejście polityczne i podejście kulturowe.

Dominujące i najbardziej obfite w publikacje podejście ekonomiczno-techniczne obejmuje literaturę $\mathrm{z}$ obszaru marketingu, zarządzania i turystyki i koncentruje się na zagadnieniach związanych ze wzrostem gospodarczym, efektywnością gospodarki oraz akumulacją kapitału. Branding narodowy rozumiany jest tutaj jako strategiczne narzędzie służące do zwiększania przewagi konkurencyjnej kraju na rynku globalnym. Tworzenie marki państwa opiera się na podobnych mechanizmach do tych, które wykorzystywane są przy tworzeniu marki komercyjnej. Przedstawicielami tego podejścia teoretycznego są $\mathrm{m}$. in. Simon Anholt, Willy Olins, Ying Fan, Jack Yan, John O’Shaughnessy.

Podejście polityczne koncentruje się przede wszystkim na pytaniu o wpływ wizerunku państwa na jego udział w globalnym systemie stosunków międzynarodowych. Prace badawcze $\mathrm{w}$ ramach tego podejścia powstają $\mathrm{w}$ obszarze stosunków międzynarodowych (Peter van Ham, Mark Leonard, Jan Melissen), public relations (Michael Kunczik, Jian Wang, Li Zhang) oraz komunikacji międzynarodowej (Eytan Gilboa, R.S. Zaharna). Punkt wyjścia do rozważań w ramach podejścia politycznego stanowi koncepcja miękkiej siły (soft power) Josepha S. Nye'a oraz idea tzw. Noopolitik, stworzona przez Johna Arquilla i Davida Rosenfeldt'a ${ }^{3}$. Obie koncepcje podkreślają znaczenie wizerunku i reputacji kraju w stosunkach międzynarodowych. Prace powstające w ramach podejścia politycznego zajmują się głównie dyplomacją publiczną, koncepcją starszą od brandingu narodowego, sięgającą lat 60. XX w.

Do tej pory najmniejszą i dopiero się rozwijającą grupę prac stanowią publikacje reprezentujące podejście kulturowe do tematu, powstające przede wszystkim w obszarze studiów kulturoznawczych i medioznawczych (Melissa Aronczyk, Michael J. Baker, Sue C. Jansen, Nadia Kaneva), rzadziej antropo-

3 Ideę Noopolitik (połączenie greckiego Noos [wiedza] i niemieckiego Politik [polityka]) zaprezentowali w 1999 roku eksperci ds obronności J. Arquilla, D. Ronfeldt w swoim raporcie dla rządowego think tanku RAND: Arquilla, J., Ronfeldt, D. (1999). The Emergence of Noopolitik: Toward an American Information Strategy. RAND. Santa Monica. 
logicznych (Dace Dzenovska). Prace te koncentrują się przede wszystkim na zbadaniu implikacji pomiędzy brandingiem narodowym a kształtowaniem się tożsamości narodowej i kulturowej społeczeństw. Opierając się na krytycznych teoriach medio- i kulturoznawczych, publikacje w ramach tego podejścia próbują wnieść do dominującego dyskursu toczącego się w ramach dwóch powyżej zaprezentowanych podejść bardziej krytyczne spojrzenie na fenomen brandingu narodowego.

W literaturze przedmiotu istnieją naturalnie prace, które łączą elementy różnych podejść teoretycznych, przy czym najczęściej łączone bywają podejścia techniczno-ekonomiczne oraz polityczne. Kategoryzację Kanevy uznaję za przydatną, ponieważ w sposób klarowny porządkuje ona literaturę poświęconą brandingowi narodowemu, przyczyniając się do pełniejszego zrozumienia kierunków rozwoju badań nad brandingiem narodowym oraz przyczyn występowania poszczególnych luk badawczych.

\section{DEFINICJA BRANDINGU NARODOWEGO}

W literaturze przedmiotu nie ma jednej wiodącej definicji brandingu narodowego. Podobnie jak marka narodowa, tak i branding narodowy są pojęciami złożonymi, stąd rozumienie tych pojęć jest zróżnicowane, zarówno jeśli chodzi o ich elementy składowe, obszar działania, jak i wyznaczone cele.

Rozważania nad definicją brandingu narodowego zacznę od przyjrzenia się jego etymologii, czyli od wyjaśnienia znaczenia słów branding i narodowy. Branding to pojęcie wywodzące się z marketingu i oznacza wg autora najpopularniejszego bodaj podręcznika akademickiego z tej dziedziny, Philipa Kotlera, budowanie marki (brand'u) i zarządzanie nią (Armstrong, Kotler, 2012). Markę definiuje on przy tym jako „nazwa, pojęcie, znak, symbol, design, względnie połączenie tych elementów, identyfikujące produkty (usługi) konkretnego producenta bądź sprzedawcy" (Armstrong, Kotler, 2012, s. 321-322). Branding służy klientom, gdyż pozwala im zidentyfikować produkty, informuje o ich jakości i stałości jej poziomu. Producentom pozwala z kolei zbudować całościową historię na temat wyjątkowości danego produktu; wraz ze znakiem handlowym zapewnia ochronę prawną niepowtarzalnych cech charakterystycznych produktu oraz pozwala dokonać segmentacji rynku. Marka to kluczowy element $\mathrm{w}$ relacji przedsiębiorstwa $\mathrm{z}$ klientami. Reprezentuje ona postrzeganie i odczucia konsumentów w odniesieniu do danego produktu i jego skuteczności, a tym 
samym istnieje wyłącznie w umysłach klientów, nie można jej więc wytworzyć „w fabryce" (Armstrong, Kotler 2012, s. 321-322).

Przymiotnik narodowy oznacza odnoszący się do narodu. Co prawda, jak twierdzi jeden z polskich socjologów, „nie ma i prawdopodobnie nie będzie takiej definicji narodu, która pasowałaby do wszystkich grup, których członkowie uporczywie uważają samych siebie za należących do jednego narodu i jako naród są postrzegani także przez ludzi należących do innych grup tego rodzaju” (Szacki, 1997, s. 15-16). Niemniej jednak, pomimo braku obiektywnych kryteriów, na podstawie których możliwe byłoby odróżnienie zbiorowości narodowej od makrospołecznych zbiorowości innego typu, istnieją pewne aspekty narodu, do których panuje niemal powszechna zgoda: Naród to bowiem byt abstrakcyjny, „wyobrażony”, związany ze sferą świadomości, tożsamości i wartości (Szacka, 2008). Podstawowym doświadczeniem członków narodu jest poczucie bliskości i podobieństw w stosunku do innych członków tej zbiorowości. Przy czym poczucie to nie tyle wynika z osobistych doświadczeń (członkowie w większości nie znają się między sobą), ile jest ono kwestią wiary wypływającą ze źródeł ideologicznych (Szacki, 1997). Fundamentalną więzią łączącą członków narodu jest wspólna świadomość narodowa, której masowe występowanie traktowane jest zarazem jako cecha stwierdzającą ukonstytuowanie się narodu (Szacki, 1997). Składnikami świadomości narodowej są z reguły wyobrażenie określonego terytorium stanowiącego własność narodu i nacechowanego pozytywnie jako ojczyzna, wiedza na temat wspólnej przeszłości historycznej i swoistej kultury narodowej, która choć znana większości członków narodu tylko pobieżnie, stanowi zazwyczaj przedmiot ich dumy i znak rozpoznawczy w stosunkach z członkami innych narodów, oraz wyobrażenie własnego państwa (Szacki, 1997). Upowszechnienie świadomości narodowej wśród mas, która to świadomość nota bene - może mieć wiele różnych artykulacji ideologicznych, jest przy tym zadaniem elit. W tym kontekście narody „mają w sobie wiele $\mathrm{z}$ „,artefaktu, wynalazku, inżynierii społecznej” (Szacki, 1997, s. 17). Narody nie tyle powstają, ile są tworzone, i to nierzadko całkiem świadomie według ideologicznego projektu „stania się narodem”. Nie ma więc narodów „bez ideologów i przywódców, którzy taki projekt układają, zabiegając następnie o to, by został zaakceptowany przez możliwie dużą część populacji zdefiniowanej przez nich jako naród" (Szacki, 1997, s. 17).

Z etymologicznego punktu widzenia branding narodowy jest więc budowaniem marki zbiorowości ludzi o wspólnej świadomości narodowej i późniejsze zarządzanie tą marką. Jak widać już na tym poziomie refleksji, istnieje wyraźny 
związek między marką narodową a świadomością narodową. Dla niektórych badaczy, np. dla Keith Dinnie i Jana Melissena, świadomość czy też tożsamość narodowa odgrywają centralną rolę w brandingu narodowym. Jan Melissen (2007) pisze: „Crucially it is about the articulation and projection of identity” (s. 20). Wg Keith Dinnie (2008) „national identity plays a key role in nation branding” (s. 111), a "key issues in national identity include viewing the nation as an 'imagined community' and the notion of 'invented tradition'” (s. 127).

$\mathrm{W}$ tym miejscu należy zaznaczyć, iż w literaturze przedmiotu pojęcie brandingu narodowego używane jest zamiennie z pojęciami brandingu państwa i brandingu kraju (nation branding, state branding and country branding). Ta sama praktyka stosowana jest także w odniesieniu do pojęcia marki narodowej, marki państwa i marki kraju (nation brand, state brand and country brand). Branding narodowy tak jak marka narodowa obejmuje wiele wymiarów jednocześnie, stąd problem z jednoznacznym rozgraniczeniem pojęć naród, państwo i kraj w kontekście budowania marki narodowej. Jak zauważają Marta Hereźniak (2011) i Kyung M. Lee (2009), marka narodowa (jako dobro narodowe współtworzone przez członków wspólnoty narodowej) jest zarazem marką państwa (odnoszącą się do jakości rządzenia i funkcjonowania instytucji państwa) oraz marką krajową (dotyczącą wyodrębnionego obszaru geograficznego). Ta argumentacja zgodna jest z wyżej zaprezentowaną definicją narodu, w której kraj, państwo oraz wiedza o historii i kulturze traktowane są jako elementy składowe świadomości narodowej koniecznej do zaistnienia narodu.

W literaturze przedmiotu koncepcję brandingu narodowego oddziela się od koncepcji marki narodowej. Jak pisze Ying Fan (2006, s. 12): „Nation Branding should be distinguished from nation brand as there is not necessarily a direct link between the two. A nation's 'brand' exists with or without any conscious efforts in nation branding, as each country has a current image to its international audience, be it strong or weak, clear or vague. In theory nation branding could help a nation to improve its image; in reality there are many other factors that affect the image and perception of the country, resulting in only a marginal role for nation branding".

Wypowiedź ta uwypukla trzy aspekty brandingu narodowego. Po pierwsze potwierdza, że państwo może być traktowane jako marka, o ile wywołuje u odbiorców konkretne skojarzenia - czyli posiada określony wizerunek/ image. Po drugie konstatuje, iż marka narodowa może istnieć niezależnie od jakichkolwiek działań brandingowych prowadzonych na rzecz jej kreowania. Po trzecie sugeruje, że wizerunek państwa, a co za tym idzie jego marka, są 
wynikiem działania różnych czynników. Branding narodowy wraz z całym jego instrumentarium stanowi jedynie jeden $\mathrm{z}$ tych czynników.

Przejdźmy teraz do omówienia spotykanych w literaturze przedmiotu definicji brandingu narodowego. Najbardziej płodna jest w tym zakresie literatura powstała w obszarze ekonomiczno-technicznego podejścia do brandingu narodowego, o którym pisałam powyżej. Najwęższe definicje w ramach tego podejścia traktują branding narodowy jako prosty synonim efektu kraju pochodzenia (country-of-origin effect) bądź synonim marketingu terytorialnego (place and destination marketing) (Fan, 2006, s. 6). Niewątpliwie właśnie w tych obszarach należy szukać korzeni brandingu narodowego, jednakże dla opisania jego istoty podejścia te wydają się być zdecydowanie zbyt wąskie. Ograniczę się więc w tym miejscu jedynie do wspomnienia istnienia tych definicji, rezygnując z ich szerszego omówienia. Związek między efektem pochodzenia, marketingiem terytorialnym a brandingiem narodowym został obszernie opracowany przez Kyung M. Lee w jego pracy doktorskiej (Lee, 2009).

Ying Fan (2006, s. 6) proponuje następującą definicję brandingu narodowego: „Nation branding concerns applying branding and marketing communications techniques to promote a nation's image". Definicja ta, wciąż w miarę wąska, utożsamia branding narodowy ze stosowaniem technik komunikacji marketingowej i brandingowej w celu promowania wizerunku kraju. Po pierwsze więc definiuje branding jako narzędzie komunikacji, po drugie stawia mu za cel promowanie wizerunku kraju, nie definiując jednakże bliżej, co to promowanie i co wizerunek kraju miałyby oznaczać.

Nieco dokładniejsza jest w tym względzie definicja Eugene D. Jaffe’a i Israela D. Nebenzahl'a. Ich zdaniem branding narodowy: „ma na celu wykreowanie zrozumiałej, prostej i zróżnicowanej idei zbudowanej wokół wartości emocjonalnych, która może być przedstawiana za pomocą werbalnych lub wizualnych środków przekazu oraz która jest zrozumiała dla różnorodnych odbiorców w różnych sytuacjach. Aby być skutecznym, branding narodowy musi obejmować działania na płaszczyźnie politycznej, kulturalnej, biznesowej oraz sportowej” (Jaffe, Nebenzahn, 2006, cytat za Fan, 2006, s. 6).

Już samo zestawienie słów „zrozumiała”, „prosta”, „zróżnicowana”, „różnorodnych” i „różnych” pokazuje złożoność natury brandingu narodowego. Wg tej definicji branding narodowy nie ogranicza się tylko do samej komunikacji marketingowej i brandingowej, lecz obejmuje różne działania w prawie wszystkich obszarach charakterystycznych dla istnienia państwa i narodu. Celem brandingu jest tutaj wykreowanie wspólnej idei nacechowanej emocjonalnie 
i prostej w przekazie (zarówno werbalnym, jak i wizualnym), którą odbiorcy utożsamiać będą z danym krajem.

W procesie brandingu narodowego kompleksowość kraju, narodu i państwa ma więc zostać uproszczona i zredukowana do klarownie i wyraziście komunikowanej „chwytliwej” idei, która poprzez pozytywne nacechowanie emocjonalne zostanie „kupiona” przez odbiorców. Tożsamość narodowa musi zostać tym samym dopasowana do potrzeb tożsamości marki. Fiona Gilmore (2002, s. 285) definiuje istotę marki narodowej jako „core ideology”, której najważniejszym zadaniem jest uchwycenie „ducha narodu” („spirit of the people of that nation and their shared purpose"), przy czym duch ten wyrażać powinien zarówno „spirit” w odniesieniu do ludzi, jak i do kraju. Branding narodowy staje się wtedy „opowiadaniem unikatowej historii i jej wyrażaniem jako zintegrowanej narracji o klarownym kształcie i celu" (Copeland, 2011, s. 186). Jak konstatuje Meike Eitel (2013), wśród teoretyków brandingu narodowego istnieje konsens co do przekonania, iż marka narodowa jest wyrazem skumulowanej tożsamości narodowej. Wskazuje ona, iż kontrowersje dotyczące definicji brandingu narodowego koncentrują się raczej wokół obszaru oddziaływania tej koncepcji, zaangażowanych podmiotów oraz stosowanych działań i narzędzi.

Jak już pisałam, analizą związku pomiędzy marką narodową, brandingiem narodowym a tożsamością narodową zajmują się przede wszystkim badacze reprezentujący tzw. podejście kulturowe do brandingu narodowego. Wg Nadii Kanevy (2011, s. 118) funkcją marki narodowej jest „rekonstrukcja narodowości, zarówno na poziomie ideologii, jak i praktyki”. Podobnie traktuje branding narodowy Dace Dzenovska (2005, s. 15), przypisując mu funkcję „odkrywania i tworzenia takiej prawdy o narodzie, która mogłaby stanowić podstawę tożsamości marki narodowej“. Proces brandingu narodowego traktuje ona jako reakcję na logikę rzeczywistości globalnej („logic of the "reality of globalization “") (Dzenovska, s. 15). Sue C. Jansen (2008, cytat za Ociepka, 2013, s. 103) precyzuje, że „branding narodowy [...] jest praktyką, która selekcjonuje, upraszcza i stosuje tylko te aspekty tożsamości narodowej, które wspierają jego urynkowienie”. Tak rozumiany branding narodowy koncentrować się będzie na uwypukleniu wyłącznie pozytywnych aspektów tożsamości narodowej. Problemy, konflikty tkwiące korzeniami w historii zostaną albo przemilczane, albo zaproponowany zostanie przekaz, który ma zastąpić istniejącą narrację.

W polskiej literaturze przedmiotu najczęściej cytowaną definicję zaproponowała Marta Hereźniak. Wg niej „branding narodowy jest procesem społecznym i zarządczym, mającym na celu zbudowanie w skali międzynarodowej wize- 
runku i reputacji kraju, pożądanych z punktu widzenia strategii jego rozwoju“ (Hereźniak, 2011, s. 23). Przyjrzyjmy się bliżej tej definicji. Po pierwsze, branding narodowy nie jest w tym rozumieniu narzędziem komunikacji, lecz procesem społecznym i zarządczym. Proces społeczny rozumiany jest przez Hereźniak jako uczestniczenie społeczeństwa w procesie kreowania marki narodowej, co równocześnie jest czynnikiem warunkującym powodzenie tego procesu. Marka narodowa musi powstawać za przyzwoleniem oraz akceptacją grup i organizacji społecznych, które powinny być stopniowo włączane w jej urzeczywistnianie. Identyfikacja $\mathrm{z}$ marką, podzielanie zawartych w niej wartości jest konieczne, by obywatele danego państwa mogli być jej reprezentantami za granicą (Hereźniak, 2011, s. 21).

Po drugie, celem brandingu narodowego wg Hereźniak jest budowanie wizerunku i reputacji kraju za granicą. Wizerunek definiowany jest tutaj jako krótkotrwałe wrażenie odbiorcy z kontaktu z konkretnym obiektem, które może często ulegać zmianom, natomiast reputacja posiada w tym rozumieniu charakter długotrwały i jako pojęcie może być zamiennie używane z pojęciem marki narodowej. Budowanie reputacji, tak jak i budowanie marki, jest procesem strategicznym, jego istotą jest tworzenie długotrwałych pozytywnych wrażeń o kraju, opartych na różnych wizerunkach i działaniach. Reputacja wynika z unikalności kraju i z działań jej przedstawicieli na rzecz kształtowania i artykułowania jego tożsamości. To właśnie dzięki reputacji kraj może być postrzegany jako wiarygodny, odpowiedzialny i godny zaufania (Hereźniak, 2011, s. 22-23).

Po trzecie, Hereźniak w swojej definicji wyraźnie podkreśla związek między wizerunkiem i reputacją a strategią rozwoju danego kraju. Branding narodowy, który pozwala zintegrować wszystkie strategiczne elementy w jedną formułę, traktowany jest tutaj jako punkt wyjścia bądź źródło inspiracji do opracowania całościowej strategii marketingu miejsca (Hereźniak, 2011, s. 23).

Trudno jest mi zaakceptować definicję brandingu narodowego w takiej formie. Po pierwsze, definiując branding narodowy w pierwszej linii jako proces społeczny Hereźniak sugeruje, że najważniejszą płaszczyzną oddziaływania brandingu jest jego wymiar wewnętrzny, czyli oddziaływanie na odbiorców krajowych. Niewątpliwie branding narodowy bez poparcia, akceptacji i identyfikacji społeczeństwa $z$ kreowaną marką jest skazany na niepowodzenie, jednakże stawianie tego aspektu na pierwszym miejscu wydaje mi się nadawać mu zbyt wyeksponowane znaczenie. Także samo użycie kategorii „procesu społecznego” wydaje się nie do końca adekwatne. Użycie słowa „proces” zakłada bowiem, że branding będzie wywoływał ciągłą serię zmian odbywających się wewnątrz 
społeczeństwa. Tak stać się co prawda może, ale nie musi. Branding narodowy ma na celu stworzenie jednej spójnej narracji, która będzie tworzyła ramy dla wszelakich działań podejmowanych na różnych polach i z którą społeczeństwo będzie się identyfikować. Identyfikacja ta może, ale nie musi prowokować zmian społecznych. Beata Ociepka mówi w tym kontekście o wewnętrznym wymiarze brandingu narodowego (Ociepka, 2013, s. 101). Simon Anholt posługuje się określeniem „live the brand” (Anholt, 2007, s. 13). Oba sformułowania wydają mi się bardziej trafne.

Problemów nastręcza także rozumienie przez Hereźniak pojęć wizerunku i reputacji, a przede wszystkim rozróżnienie między nimi na podstawie krótko- i długofalowego horyzontu czasowego. Już popularne powiedzenie, że dobrą reputację długo się zdobywa, ale bardzo szybko traci, zdaje się przeczyć pojmowaniu reputacji jako kategorii o charakterze długotrwałym. Przyjrzyjmy się dokładniej obu tym pojęciom: Wizerunek to „złożona intelektualna lub zmysłowa interpretacja, sposób postrzegania kogoś lub czegoś; wytwór umysłu wynikający z dedukcji opartej na dostępnych przesłankach, zarówno realnych, jak i wyobrażonych, uwarunkowany wrażeniami, przekonaniami, ideami i emocjami” (Davis, 2007, s. 47). Reputację należy z kolei „odnieść do stopnia szacunku i poważania, jakim cieszy się określona instytucja bądź organizacja” (Szadok-Bratuń, 2012, s. 36). Zarówno reputacja, jak i wizerunek powstają jako suma i wypadkowa informacji, wrażeń i odczuć w umyśle odbiorcy, reputacja jest jednak oparta na wartościowaniu (Szadok-Bratuń, 2012, s. 36), a jej podstawą są doświadczenia zdobyte w kontaktach z daną instytucją bądź organizacją (Davis, 2007, s. 52). Kluczowymi czynnikami wpływającymi na tworzenie się reputacji są wiarygodność, uczciwość, poziom etyki działań, historia, wyznawane i realizowane wartości w relacjach zarówno zewnętrznych, jak i wewnętrznych (Szadok-Bratuń, 2012, s. 37). Hereźniak (2013, s. 22-23) ma niewątpliwie rację, pisząc, że dzięki reputacji „kraj jest postrzegany jako wiarygodny, odpowiedzialny i godny zaufania", zapomina jednak o tym, że te same cechy są konieczne, aby ta reputacja mogła powstać. Gdyby, jak pisze Hereźniak (2013, s. 22-23), reputacja wynikała „Z unikalności kraju oraz z działań jego przedstawicieli na rzecz kształtowania i artykułowania jego tożsamości”, to kraje takie jak Birma czy Rosja po aneksji Krymu w 2014 r. powinny cieszyć się wyjątkowo pozytywnymi reputacjami. A tak przecież nie jest.

W definicji Hereźniak na uwagę zasługuje przedstawienie brandingu narodowego jako procesu zarządczego oraz połączenie go ze strategią rozwoju państwa. Takie ujęcie zbliża autorkę do rozumienia brandingu narodowego reprezentowa- 
nego przez Nickolasa Papadopoulos'a, Keith Dinnie, a przede wszystkim przez Simona Anholt'a, twórcę pojęcia i do dziś jednego z największych autorytetów na tym polu (por. Papadopoulos, 2004; Dinnie, 2009; Anholt, 2007). Dla wszystkich tych badaczy branding narodowy jest czymś więcej niż tylko koncepcją marketingową czy koncepcją łączącą pojedyncze strategie komunikacyjne w jedną całość. Wszyscy oni kładą szczególny nacisk na gospodarczo-polityczne i społeczno-polityczne aspekty oddziaływania brandingu narodowego, upatrując w nim swoistego impulsu innowacyjnego dla gospodarczego, politycznego oraz społecznego rozwoju kraju (Eitel, 2013). Papadopoulos wyodrębnia np. cztery podstawowe cele brandingu narodowego: wzrost eksportu, ochronę rodzimej gospodarki przed konkurencją zagraniczną, innowacje i rozwój oraz tworzenie korzystnych warunków ekonomicznych, politycznych i socjalnych kraju (Eitel, 2013). Podczas gdy dwa pierwsze wymienione cele zakwalifikować można do typowych celów marketingowych, dwa pozostałe zdecydowanie wpisują się w szerzej rozumianą strategię rozwoju państwa.

Najszersze, a zarazem najbardziej ambitne podejście do brandingu narodowego reprezentuje Simon Anholt ${ }^{4}$. W jego przekonaniu ograniczanie rozumienia zarządzania marką wyłącznie do tworzenia tożsamości wizualnych lub organizowania kampanii promocyjnych, czyli myślenia o marce w kategoriach logo i haseł reklamowych, jest myśleniem naiwnym, które skazuje kraje, miasta i regiony na wyrzucanie w błoto olbrzymich pieniędzy na nieskuteczną propagandę (Anholt, 2007). Według niego podobnie jak idea zarządzania marką okazała się jednym z najlepszych instrumentów planowania strategicznego i generowania bogactwa w sektorze komercyjnym, tak jej zastosowanie do pobudzania rozwoju oraz konkurencyjności państw, regionów i miast może przynieść w następnych latach ogromne i bardzo dalekosiężne efekty" (s. 3).

Branding wg Anholta (2007, s. 11) to „proces lub procedura projektowania, planowania i komunikacji nazwy oraz tożsamości (produktu, usługi czy instytucji) w celu zbudowania i/albo zarządzania jego/jej reputacją”. Branding narodowy z kolei to: „systematic process of aligning the actions, behaviours, investments, innovations and communications of a country around a clear

\footnotetext{
4 W roku 2007 Anholt zmienił nazwę swojej koncepcji z brandingu narodowego na koncepcję tożsamości konkurencyjnej kraju. Zmianę tę, merytorycznie marginalną, uzasadnia stwierdzeniem, iż, „tożsamość konkurencyjna” ma „więcej wspólnego z tożsamością narodową oraz polityką i ekonomią konkurencyjności niż z brandingiem", który dla wielu odbiorców jest negatywnie zaszufladkowany w języku marketingu komercyjnego, zorientowanego w pierwszej linii na zwiększenie sprzedaży. Zob. S. Anholt, Tożsamość konkurencyjna. Nowe spojrzenie na markę, Warszawa 2007, s. $1 \mathrm{ff}$.
} 
strategy for achieving a strengthened competitive identity. It can be as modest as linking the promotions [...], or it can be a decades-long policy of coordinating all internal and external national strategies [...] into a coherent, planned proces" (Lee, 2009, s. 14).W idealnym wypadku branding narodowy jest więc najbardziej całościową długoterminową strategią rozwoju marki narodowej, która obejmuje szeroko zakrojoną wizję przyszłości państwa wraz z zapewnieniem spójnego komunikowania tej wizji reszcie świata.

Dla Anholta branding narodowy stanowi zatem gospodarczo-polityczny proces zarządczy, komponent polityki narodowej (Anholt, 2007, s. 49), którego obszar działania wyznaczony jest przez tzw. Nation Branding Hexagon (Rysunek 1), sześciokąt obrazujący kanały komunikacji, którymi państwo rozmyślnie lub przypadkowo komunikuje się z resztą świata, budując przy tym swoją reputację. Poczynając od dyplomacji publicznej (polityka wewnętrzna i zagraniczna), poprzez eksport, turystykę, inwestycje zagraniczne i migracje, a kończąc na ludziach oraz kulturze i dziedzictwie, sześciokąt ten, a co za tym idzie, branding narodowy, obejmuje praktycznie wszystkie obszary związane $\mathrm{z}$ istnieniem państwa i narodu. Podstawowym założeniem jest przy tym stworzenie jednej, spójnej, jasnej, pozytywnej i wiarygodnej wizji kraju, która pozwoli efektywnie koordynować i zarządzać działaniami inwestycyjnymi, politycznymi oraz komunikacyjnymi na wszystkich wierzchołkach powyższego sześciokąta (Anholt, 2007). Wizja ta, czy inaczej „wiarygodne i atrakcyjne story kraju” (Anholt, 2007, s. 47), aby być skuteczne, musi mieć pokrycie wśród udziałowców i interesariuszy kraju, takich jak sektor turystyczny, agencje inwestycyjne, przedsiębiorcy, władze centralne czy zwykli obywatele. Inaczej mówiąc, musi przeniknąć ona głęboko do wewnętrznych struktur państwa i tam zdobywać akceptację poszczególnych grup społecznych, żeby w efekcie można było mówić o „wspólnocie celu”, czy tzw. życiu marką (live the brand). Jak zauważa Fiona Gilmore (2002, s. 291-292), zadaniem brandingu narodowego jest takie wpłynięcie na obywateli kraju, by stali się oni nie tylko zwolennikami, ale i aktywnymi „ambasadorami marki”: "In order to stem the brain drain and also to encourage these individuals to contribute to nation building efforts, they need to be converted to 'believers' through country branding".

Pojęciami centralnymi w rozumieniu brandingu narodowego przez Anholta są innowacje i innowacyjność. Branding narodowy ma nie tylko komunikować potencjał innowacyjny kraju, ale go przede wszystkim wyzwalać, ukierunkowywać i nim zarządzać. Przy czym celem nadrzędnym pozostaje dbałość o międzynarodową reputację kraju. „[...] the idea of not merely stimulate innovation, but 


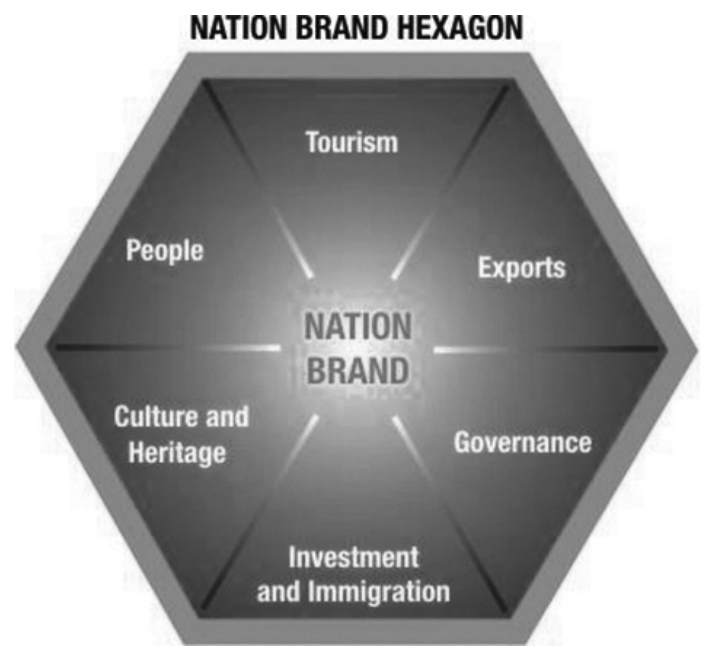

\section{Rysunek 1. Sześciokąt brandingu narodowego (tożsamości konkurencyjnej) wg Simona Anholta \\ Źródło: Rated Ranking: Anholt-GfK Roper Nation Brands Index 2013 (2013). Pobrane z: http://www.branding-institute.com/rated- -rankings/anholt-gfk-roper-nation-brands-index.}

aligning the innovation to a strategy for enhancing the country's international reputation" (Anholt, 2010, s. 12). Jak słusznie zauważa Meike Eitel (2013), takie podejście do brandingu narodowego jest, z punktu widzenia systemu demokratycznego, problematyczne. Jeśli branding narodowy jest nie tylko narzędziem komunikacji, lecz także procesem zarządczym ingerującym w strategię rozwoju państwa, bądź wręcz wyznaczającym kierunki jego rozwoju, to w pluralistycznym społeczeństwie pojawia się pytanie o jego legitymizację. Czy strategiczne decyzje dotyczące kierunków rozwoju państwa mogą być podejmowane na podstawie rad ekspertów od marketingu i zarządzania marką, czy powinny raczej być efektem prowadzonych dyskursów politycznych i publicznych?

Powyższe rozważania ukazują, jak różne jest rozumienie brandingu narodowego wśród badaczy zjawiska, przy czym prezentując i omawiając poszczególne definicje próbowałam uporządkować je od najwęższych do najszerszych. Cechą wspólną wszystkich definicji jest postrzeganie brandingu narodowego jako narzędzia promowania pozytywnego wizerunku i reputacji państwa za granicą. Różnice i najważniejsze kontrowersje dotyczą przede wszystkim obszaru oddziaływania, zaangażowanych podmiotów oraz stosowanych działań i narzędzi. 
Postrzeganie brandingu narodowego wyłącznie jako narzędzia komunikacji jest w moim przekonaniu podejściem zbyt wąskim, pomija ono bowiem całkowicie występowanie gospodarczo-politycznych oraz społeczno-politycznych aspektów oddziaływania tej koncepcji. Bliższe jest mi traktowanie brandingu narodowego jako długoterminowej strategii rozwoju marki narodowej, która z jednej strony wyraża tzw. ducha narodu, przez co pozwala społeczeństwu się z nią identyfikować, z drugiej zaś obejmuje szeroko zakrojoną wizję przyszłości państwa wraz z zapewnieniem spójnego komunikowania tej wizji reszcie świata. W tym sensie rację mają badacze tacy jak Papadopoulos, Dinnie czy Anholt, upatrując w brandingu narodowym swoistego impulsu innowacyjnego dla gospodarczego, politycznego oraz społecznego rozwoju kraju. Na ile jednak, jak postuluje Anholt, branding narodowy stanowi gospodarczo-polityczny proces zarządczy, będący komponentem strategii narodowej, pozostaje w moim przekonaniu pytaniem otwartym. Postulat Anholta wyraża bowiem bardziej pewne życzenie dotyczące dalszego rozwoju i możliwości wdrażania koncepcji brandingu narodowego niż oddaje stan faktyczny oparty na analizie stosowania koncepcji brandingu przez poszczególne państwa. Nie ulega wątpliwości, iż udany branding narodowy musi być komplementarny z całościową strategią rozwoju państwa. Poprzez opisaną powyżej zdolność do bycia impulsem dla procesów innowacyjnych powinien on być także uwzględniony przy tworzeniu takiej strategii. $\mathrm{Na}$ ile jednak koncepcje marketingowe czy brandingowe mogą zastąpić tradycyjne mechanizmy zarządzania państwem, pozostaje dla mnie sprawą wątpliwą. Jednym $\mathrm{z}$ centralnych pytań jest tu poruszone już wcześniej pytanie o legitymizację stosowania tych koncepcji w polityce.

Mając na uwadze powyższe refleksje, proponuję następującą definicję brandingu narodowego: Branding narodowy to długoterminowa strategia rozwoju marki narodowej w celu zbudowania i zarządzania wizerunkiem i reputacją kraju, pożądanych z punktu widzenia jego rozwoju i ułatwiających realizację jego interesów w środowisku międzynarodowym. Marka narodowa to spójna kompozycja nazwy, pojęć, znaków, symboli i design'u, służąca identyfikacji kraju i wyrażająca pewną nadrzędną i unikalną ideę nacechowaną emocjonalnie, która z jednej strony stanowi wyraz tożsamości narodowej, z drugiej obejmuje długoterminową wizję rozwoju państwa. 


\section{PODSUMOWANIE}

Branding narodowy jest stosunkowo młodą koncepcją, która od momentu swojego powstania cieszy się nieustająco rosnącym zainteresowaniem zarówno wśród badaczy naukowych, jak i praktyków. Idea traktowania państwa jako marki oraz kształtowania tej marki i zarządzania nią na wzór kreowania i zarządzania markami komercyjnymi zdaje się odpowiadać współczesnym potrzebom państw szukających skutecznych metod pozycjonowania oraz zdobywania przewag konkurencyjnych w zmieniającym się środowisku międzynarodowym.

W badaniach naukowych nad brandingiem narodowym wyróżnić można obecnie trzy zasadnicze podejścia teoretyczne: ekonomiczno-techniczne, polityczne i kulturowe, o których pisałam w niniejszym artykule. Sama koncepcja brandingu narodowego wywodzi się z marketingu - wobec czego nie dziwi fakt, iż najobszerniejszą literaturę na ten temat możemy spotkać właśnie w obszarze tej dziedziny oraz w obszarach zarządzania i turystyki (podejście ekonomiczno-techniczne). Marka narodowa oraz związane z nią pojęcia wizerunku i reputacji państwa traktowane są często jako elementy tzw. miękkiej siły państwa i zazwyczaj w tym kontekście rozpatrywane przez badaczy z obszaru stosunków międzynarodowych, public relations i komunikacji politycznej (podejście polityczne). Krytyczne prace na temat brandingu narodowego powstają głównie w obszarze studiów kulturoznawczych, medioznawczych czy antropologicznych i poświęcone są badaniu implikacji pomiędzy brandingiem narodowym a kształtowaniem się tożsamości narodowej i kulturowej społeczeństw. W ostatnich latach zauważalny jest wzrost ilości prac poświęconych brandingowi narodowemu, które charakteryzuje interdyscyplinarne podejście, łączące różne dyscypliny naukowe. Jestem przekonana, iż tendencja ta będzie się nasilała. Wymagać tego będzie rosnąca potrzeba całościowego potraktowania fenomenu brandingu narodowego, a nie zajmowania się jedynie jego wybranymi aspektami.

Jak wykazałam w niniejszym artykule, nie istnieje jedna, spójna i powszechnie akceptowana definicja brandingu narodowego. Trudno także, w obliczu zaprezentowanej powyżej rozpiętości pojmowania terminu, mówić o jednej dominującej koncepcji brandingu narodowego. W literaturze przedmiotu spotykamy się z bardzo różnym rozumieniem tego pojęcia, począwszy od utożsamiania go z prostym narzędziem marketingowym, aż po upatrywanie w nim elementu długookresowej strategii rozwoju państwa. Częścią łączącą wszystkie te podejścia jest przypisywanie brandingowi narodowemu celowego oddziaływania na wizerunek i reputację państwa za granicą, a także postrzeganie go jako rodzaju 
skumulowanej tożsamości narodowej. Kontrowersje skupiają się wokół problemu określenia poszczególnych obszarów oddziaływania brandingu narodowego, zaangażowanych podmiotów oraz stosowanych działań i narzędzi. Zaproponowaną przeze mnie definicję brandingu narodowego należy umiejscowić wśród definicji reprezentujących szersze rozumienie tego pojęcia, wykraczające poza traktowanie brandingu narodowego wyłącznie jako narzędzia komunikacji. Brandingowi narodowemu przypisuję bowiem zdolność do bycia impulsem dla procesów innowacyjnych mogących wspierać pożądany rozwój wybranych obszarów państwa. Krytycznie przy tym odnoszę się do daleko idących funkcji wkraczających w obszar aktywnego zarządzania państwem, które brandingowi narodowemu wyznacza Simon Anholt, widząc w nim gospodarczo-polityczny proces zarządczy będący komponentem strategii narodowej.

\section{BibLIOGRAFIA:}

Anholt, S. (2010). Places. Identity, Image and Reputation. London: Palgrave MacMillan. Anholt, S. (2007). Tożsamość konkurencyjna. Nowe spojrzenie na markę. Warszawa: Instytut Marki Polskiej.

Anholt, S., Hildreth, J. (2010). Brand America: The making, unmaking and remaking of the greatest national image of all time. London: Marshall Cavendish Business.

Armstrong, G., Kotler, Ph. (2012). Marketing. Wprowadzenie. Warszawa: Oficyna a Wolters Kluwer business.

Aronczyk, A. (2008). "Living the Brand": Nationality, Globality and the Identity Strategies of Nation Branding Consultants. International Journal of Communication, 2008 (2), s. 41-65.

Copeland, D. (2011). The seven paradoxes of public diplomacy. W: A. Fischer, S. Lucas (red.), Trials of Engagement. The future of Public Diplomacy. Leiden: Martinus Nijhoff Publishers.

Davis, A. (2007). Public Relations. Warszawa: Polskie Wydawnictwo Ekonomiczne.

Dinnie, K. (2008). Nation branding: Concepts, issues, practice. Oxford: Elsevier.

Dzenovska, D. (2005). Remaking the nation of Latvia: anthropological perspectives on nation branding. Place Branding, 1(2), s. 173-186.

Eitel, E. (2013). Reputationskommunikation von Ländern. Instrumente und Erfolgsfaktoren - Theoretische Ansätze und Untersuchung der Kommunikationspraxis am Fallbeispiel Schweiz. Potsdam: Dissertation an der Universität Potsdam.

Fan, Y. (2006). Branding the nation: What is being branded?. Journal of Vacation Marketing, 12 (1), s. 5-14.

Gilboa, E. (2008). Searching for a Theory of Public Diplomacy. Annals of the American Academy of Political and Social Science, $n r$ 616, s. 55-77.

Gilmore, F. (2002). A country - can it be repositioned? Spain - the success story of country branding. The Journal of Brand Management, 9 (4-5), s. 281-293. 
Hereźniak, M., Marka narodowa. Jak skutecznie budować wizerunek i reputację kraju. Warszawa: Polskie Wydawnictwo Ekonomiczne.

Jaffe, E.D., Nebenzahn, I.D. (2001). National Image and Competitive Advantage: The theory ad Practice of Country-of-Origin Effect. Frederiksberg: Copenhagen Busininess School Press.

Jansen, S.C. (2008). Designer nations: Neo-liberal nation branding - Brand Estonia. Social Identities, 1(14), s. 121-142.

Kaneva, N. (2011). Nation Branding: Toward an Agenda for Critical Research. International Journal of Communication, nr 5, s. 117-141.

Lee, K.M. (2009). Nation branding and sustainable competitiveness of nation. Pobrane z: http://doc.utwente.nl/60754/1/thesis_K_M_Lee.pdf.

Melissen, J. (2007). The New Public Diplomacy. Soft Power in International Relations. London: Netherlands Institute of International Relations Clingendael.

Nye, J.S. (2004). Soft power: The means to success in world politics. New York: Public Affairs.

Ociepka, B. (2013). Miękka siła i dyplomacja publiczna Polski. Wrocław: Wydawnictwo Naukowe SCHOLAR.

Olins, W. (2004). O marce. Warszawa: Instytut Marki Polskiej.

Papadopoulos, N. (2004). Place branding: Evolution, meaning and implications. Place Branding, $n$ r 1, s. 36-49.

Porter, M.E. (2001). Porter o konkurencji. Warszawa: Polskie Wydawnictwo Ekonomiczne.

Risen, C. (2005). Branding nation. The New York Times Magazine. Pobrane z: http:// www.nytimes.com/2005/12/11/magazine/11ideas1-5.html?_r=0.

Szacka, B. (2008). Wprowadzenie do socjologii. Warszawa: Oficyna Naukowa.

Szacki, J. (1997). O narodzie i nacjonalizmie. Znak, 3 (502), s. 4-32.

Szadok-Bratuń, A., Bratuń, M. (2012). O wizerunku. W: M. Tabernacka (red.), Public Relations w sferze publicznej. Wizerunek i komunikacja, s. 25-46. Warszawa: Wolters Kluwer Polska.

Van Ham, P. (2011). Rise of the Branding State. The Postmodern Politics of Image and Reputation. Foreign Affairs, 80 (5), s. 2-6. 